IRSH 63 (20I8), Special Issue, pp. I-24 doi:I0.10I7/So0208590I 8000 I 96 (C) 20 I 8 Internationaal Instituut voor Sociale Geschiedenis

\title{
Transportation, Deportation and Exile: Perspectives from the Colonies in the Nineteenth and Twentieth Centuries*
}

\author{
Christian G. De Vito \\ School of History, Politics and International Relations \\ University of Leicester \\ University Road, Leicester $L E_{I}>R H, U K$ \\ E-mail: christian.devito@gmail.com \\ CLARE A N DERSON \\ School of History, Politics and International Relations \\ University of Leicester \\ University Road, Leicester $L_{I} 7 R H, U K$ \\ E-mail: ca26@le.ac.uk \\ UL B E B OSMA \\ International Institute of Social History \\ PO Box 2 I69, I000 CD \\ Amsterdam, The Netherlands \\ E-mail: ubo@iisg.nl
}

\begin{abstract}
The essays in this volume provide a new perspective on the history of convicts and penal colonies. They demonstrate that the nineteenth and twentieth centuries were a critical period in the reconfiguration of empires, imperial governmentality, and punishment, including through extensive punitive relocation and associated extractive labour. Ranging across the global contexts of Africa, Asia, Australasia, Japan, the Americas, the Pacific, Russia, and Europe, and exploring issues of criminalization, political repression, and convict management alongside those of race, gender, space, and circulation, this collection offers a perspective from the colonies that radically transforms accepted narratives of the history of empire and the history of punishment. In this introduction, we argue that a colony-centred perspective reveals that, during a critical period in world history, convicts and penal colonies created new spatial hierarchies, enabled the incorporation of territories into
\end{abstract}

* The research leading to these results has received funding from the European Research Council under the European Union's Seventh Framework Programme (FP/2007-2013) / ERC Grant Agreement 3 I 2542. 
spheres of imperial influence, and forged new connections and distinctions between "metropoles" and "colonies". Convicts and penal colonies enabled the formation of expansive and networked global configurations and processes, a factor hitherto unappreciated in the literature.

\section{INTRODUCTION}

Penal transportation, deportation, and exile have played a crucial role in the history of nations and empires. Without them, many colonial projects would not have materialized, or only at a much later stage. Punitive mobility helped to govern and manage populations, expand empires, and bring coerced labour to the peripheries of empires. It reinforced spatial hierarchies, created new circuits of imperial movement, and allowed colonial powers to deploy a repertoire of punitive measures within and beyond the criminal justice system. In addressing these themes, the articles in this special issue are situated at the intersection of the history of punishment, of

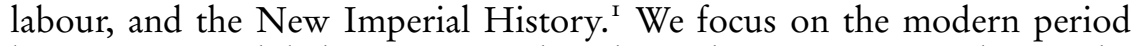
because more global powers employed penal transportation during the third quarter of the nineteenth century than at any other point in world history. Interestingly, this was at precisely the time when states unified their legal systems, modern prisons putatively emerged as sites of discipline and punishment, and forms of penal mobility and confinement diversified, owing in part to political factors. ${ }^{2}$ These penal transportations, usually to territories outside the jurisdiction of imperial parliaments, allowed for politically expedient deflections from these projects of unification of the administration of justice. In the colonies, the punitive relocation of colonial subjects both enabled and enacted imperial modes of governance and population control. At the same time, the relocation of convicts served the purpose of empire-building, which, in terms of geographical reach and scale, was at its height between the late nineteenth and early twentieth centuries.

The routes of penal transportation, deportation, and exile were determined by a hierarchically ordered relationship between different parts of the empire. Colonial subjects were rarely deported to Europe, whereas hundreds of thousands of Europeans (and if we include Soviet Russia, millions) were sent to the outskirts of colonial empires. Moreover, empires

I. Antoinette Burton and Tony Ballantyne (eds), World Histories From Below: Disruption and Dissent, 1750 to the Present (London, 2016); Durba Ghosh, "Another Set of Imperial Turns?”, American Historical Review, I 17:3 (2012), pp. 772-793; Stephen Howe (ed.), The New Imperial Histories Reader (London, 2010); Kathleen Wilson (ed.), A New Imperial History: Culture, Identity, and Modernity in Britain and the Empire, I660-I 840 (Cambridge, 2004).

2. Mary Gibson, "Global Perspectives on the Birth of the Prison", American Historical Review, II 6:4 (20I I), Pp. I040-I063. 
moved colonially convicted imperial subjects and citizens around colonial peripheries to a remarkable degree. ${ }^{3}$ Since these movements were crucial for the population of sparsely or non-settled territories, they were also often permanent. However, though convicts were sometimes the first choice in terms of labour supply, in some locations, at a later stage, non-punitive migration might take over. This was the result of a full incorporation of colonized spaces, the achieved independent statehood of former colonies, or the emergence of alternative strategies of colonization. It is the practices and processes that occurred within these colonized spaces that interest us primarily in this volume. By foregrounding the perspective of the colonies, rather than that of colonizing powers, this special issue highlights the dual character of convict mobility - that is to say, it proposes that it was both a means of imperial consolidation and a means of creating new forms of spatial distinction.

The volume's perspective is the culmination of a thorough transformation of the scholarship on convict transportation over the past forty years. This began with studies in the I980s and I990s of European transportation outwards from Europe as a means of colonization, or towards already colonized territories: from Britain to the Americas and the Australian colonies, from Spain to the Caribbean, and from China's core region to its borderlands. ${ }^{4}$ During the same period, research was conducted on interimperial transportations within the British Empire, notably from the Caribbean and Cape colonies to those of Australia. ${ }^{5}$ Then, in the early 2000s, new work stressed intra-imperial movements in other contexts. This included Timothy J. Coates' work on the Portuguese Empire (Convicts and Orphans), and Kerry Ward's Networks of Empire, which explored banishment and convict transportation in the Dutch East India Company. The focus of Networks of Empire on the connections between the Cape and Batavia joined Clare Anderson's Convicts in the Indian Ocean in pointing to the relevance of inter-colonial routes of penal transportation, and

3. Clare Anderson, "Introduction: A Global History of Convicts and Penal Colonies", in idem (ed.), A Global History of Convicts and Penal Colonies (London, 2018), pp. I-35.

4. Ian Duffield and James Bradley (eds), Representing Convicts: New Perspectives on Convict Forced Labour Migration (London, 1997); Roger Ekirch, Bound for America: The Transportation of British Convicts to the Colonies, I7I8-I775 (Oxford, 1987); Steven Nicholas (ed.), Convict Workers: Reinterpreting Australia's Past (Cambridge, I988); Ruth Pike, Penal Servitude in Early Modern Spain (Madison, WI, I983); Joanna Waley-Cohen, Exile in Mid-Qing China: Banishment to Xinjiang, $1758-1820$ (New Haven, CT, I991).

5. Lesley C. Duly, “'Hottentots to Hobart and Sydney': The Cape Supreme Court's Use of Transportation, I 828-38”, Australian Journal of Politics and History, $25: \mathrm{I}$ (1979), pp. 39-50; Ian Duffield, "From Slave Colonies to Penal Colonies: The West Indian Convict Transportees to Australia", Slavery and Abolition, 7:I (1986), pp. $25-45$; Vertrees Canby Malherbe, "Khoikhoi and the Question of Convict Transportation from the Cape Colony, 1820-1842", South African Historical Journal, 17:I (1985), pp. 19-39. 
represented major shifts in the understanding of punishment, mobility, and convict experience. ${ }^{6}$ This focus has also characterized the third, and present, generation of studies, dating from c.2010, which have stressed the significance of convict transportation in other national and imperial contexts. This body of work includes research on Germany, Italy, France, the Habsburg Empire, the Ottoman Empire, the Iberian empires, Latin America, and the empire of Denmark-Sweden, and has widened the field to studies of galley servitude, deportation, and exile. As well as expanding our knowledge of specific contexts, this, in turn, has enhanced our understanding of the larger global context for the British, French, Russian, Soviet, and Dutch cases. ${ }^{7}$

6. Clare Anderson, Convicts in the Indian Ocean: Transportation from South Asia to Mauritius, 1815-53 (Basingstoke, 2000); Timothy J. Coates, Convicts and Orphans: Forced and StateSponsored Colonizers in the Portuguese Empire, I550-1755 (Stanford, CA, 200I); Kerry Ward, Networks of Empire: Forced Migration in the Dutch East India Company (Cambridge, 2008).

7. For an overview, see Anderson, "Introduction". See also Clare Anderson and Hamish Maxwell-Stewart, "Convict Labour and the Western Empires, I4I 5-1954", in Robert Aldrich and Kirsten McKenzie (eds), The Routledge History of Western Empires (London, 2013), pp. I02-1 17. Regional studies include: Ricardo D. Salvatore and Carlos Aguirre, "Colonies of Settlement or Places of Banishment and Torment? Penal Colonies and Convict Labour in Latin America, c.1800-1940", in Christian G. De Vito and Alex Lichtenstein (eds), Global Convict Labour (Leiden, 2016), pp. 273-309; Clare Anderson, “A Global History of Exile in Asia, c.1700-1900”, in Ronit Ricci (ed.), Exile in Colonial Asia: Kings, Convicts, Commemoration (Honolulu, HI, 2016), pp. 20-47; Timothy J. Coates, Convict Labor in the Portuguese Empire, 1740-1932: Redefining the Empire with Forced Labor and New Imperialism (Leiden, 2014); Timothy J. Coates, "The Long View of Convict Labour in the Portuguese Empire, I4I I-I932", in De Vito and Lichtenstein, Global Convict Labour, pp. I44-I67; Christian G. De Vito, "Convict Labor in the Southern Borderlands of Latin America (c.1750s-1910s): Comparative Perspectives", in Marcel van der Linden and Magaly Rodríguez García (eds), On Coerced Labor: Work and Compulsion after Chattel Slavery (Leiden, 20I6), pp. 98-I 26; Matthew P. Fitzpatrick, Purging the Empire: Mass Expulsions in Germany, I87I-I9I4 (Oxford, 201 5); J.M. Gheith and K.R. Jolluck, Gulag Voices: Oral Histories of Soviet Incarceration and Exile (Basingstoke, 2010); A.A. Gentes, Exile to Siberia, I590-I 822 (Basingstoke, 2008); idem, Exile, Murder and Madness in Siberia, I823-6I (Basingstoke, 2010); Johan Lund Heinsen, Mutiny in the Danish Atlantic World: Convicts, Sailors and a Dissonant Empire (London, 2017); Miranda F. Spieler, Empire and Underworld: Captivity in French Guiana (Cambridge, MA, 20I 2); Jean-Lucien Sanchez, À perpétuité. Relégués au bagne de Guyane (Paris, 2013); Stephan Steiner, "'An Austrian Cayenne': Convict Labour and Deportation in the Habsburg Empire of the Early Modern Period", in De Vito and Lichtenstein, Global Convict Labour, pp. I26-I43. An important sub-field is represented by the study of penal servitude in the galleys: Marc Vigié, Les galériens du roi, I66I-I7IS (Paris, I985); Nicole Castan, André Zysberg, and Jacques-Guy Petit, Histoire des galères, bagnes et prisons en France de l'Ancien Régime (Toulouse, i99i); José Luis de las Heras, "Los galeotes de la monarquía hispánica durante el antiguo régimen”, Studia histórica, 22 (2000), pp. 283-300; Luca Lo Basso, Uomini da remo. Galee e galeotti del Mediterraneo in età moderna (Milan, 2003); David Wheat, "Mediterranean Slavery, New World Transformations: Galley Slaves in the Spanish Caribbean, 1578-1635", Slavery and Abolition, 31:3 (2010), pp. 327-344; Fariba Zarinebaf, Crime and Punishment in Istanbul, I700-I800 (Berkeley, CA, 2010); Manuel Martínez Martínez, Los forzados de marina en la España del siglo XVIII (I700-1775) (Almería, 20I I). 
More generally, its multi-century chronological scope, focus on a wide range of national and imperial contexts, and concern with punitive regimes associated with spatial mobility have placed the scholarship on convict transportation at the forefront of new trends in the history of unfree labour migration. This has blurred distinctions between "free" and "unfree", and incorporated military service, labour circulation, and sojourning into the analysis. ${ }^{8}$ The enduring character of punitive relocation since the Portuguese Empire first used convicts for colonizing purposes in I4I 5 has also challenged the dominant narrative of the history of punishment as a story of the demise of corporal sanction and the rise of penitentiary systems. This is still largely based on Michel Foucault's Eurocentric view of a linear development that took place around the end of the eighteenth century, culminating in the "triumphant prison" of the nineteenth and twentieth centuries. $^{9}$

The richness and diversity of the literature on convict transportation means that we are now at the stage at which we can meaningfully discuss more than their significance for the history of migration and punishment - that is to say, the connectivity and interdependence between the evolution of punitive regimes, colonial labour mobility, and empire- and nation-building. ${ }^{\mathrm{IO}}$ This special issue comprises a set of essays on practices of administrative and penal relocations in the British, Dutch, French, Japanese, Russian, Portuguese, Spanish, US, and Italian empires during the period from the nineteenth to the mid-twentieth centuries. All the papers begin

8. Clare Anderson et al., "Locating Penal Transportation: Punishment, Space, and Place c. 1750 to 1900", in Karen M. Morin and Dominique Moran (eds), Historical Geographies of Prisons: Unlocking the Usable Carceral Past (London, 2016), pp. I47-167; Tom Brass and Marcel van der Linden (eds), Free and Unfree Labour (Berne, I 997); Ulbe Bosma, "European Colonial Soldiers in the Nineteenth Century: Their Role in White Global Migration and Patterns of Colonial Settlement", Journal of Global History, 4:2 (2009), pp. 317-336.

9. Michel Foucault, Discipline and Punish: The Birth of the Prison (London, 1977). See also David Garland, Punishment and Modern Society: A Study in Social Theory (Oxford, I991), chs 6 and 7. I०. This approach was first pioneered at the University of Leicester, during the I999 conference "Colonial Spaces, Convict Places: Penal Transportation in Comparative Global Perspective". Since ${ }_{201} 3$, Leicester has hosted the ERC-funded project "The Carceral Archipelago: Transnational Circulations in Global Perspective, I4 I 5-1960", which has encompassed new research on penal transportation within British Asia, the Australian colonies, Bermuda, Gibraltar, Zanzibar, the British Caribbean, Cape Colony, French Guiana, New Caledonia, the Spanish Empire, Ecuador, Russia (Sakhalin), and Japan (including Hokkaido). Since 20I4, the NWO project "Four Centuries of Labour Camps: War, Rehabilitation, Ethnicity", based at the International Institute of Social History (IISH) and the Institute for War, Holocaust and Genocide Studies (NIOD), Amsterdam, has focused particularly on labour camps, working on the Netherlands Indies, Hamburg, Italy and the Italian colonies, and imperial and Soviet Russia. For the Carceral Archipelago project, see http://www2.le.ac.uk/departments/history/research/grants/CArchipelago and www.convictvoyages.org; last accessed i I March 2018. For the Labour Camps project, see https://www.nwo.nl/en/research-and-results/research-projects/i/90/ı0790.html; last accessed I I March 20 I 8. 
their analysis from the colonies, and by doing so they make three crucial analytical interventions. First, they focus on how understandings of class, ethnicity, race, and gender in the colonies are influenced by the sometimes conflicting demands associated with the organization of punishment and the management of labour. They integrate discussions about the flows of convicts sentenced in the framework of criminal justice systems (penal transportation), the mobilization of individuals through special laws and orders (administrative deportation), and the relocation of military and non-military individuals by means of military courts and authorities (military deportation). It is for this reason that we refer to these flows collectively as "punitive relocations". This special issue interrogates the relationships between punitive practices and their links with legal cultures, criminological knowledge, strategies of social control, and labour extraction. It addresses the interplay between groups of individuals, types of punishment, and penal destinations.

Second, these papers address the multiple interactions between punitive relocations and modes of incarceration. The contributions in this special issue join a growing body of scholarship in highlighting the point that punishment in the colonies was only marginally, if at all, related to imprisonment, because capital and corporal punishment and penal servitude continued to play a central role. ${ }^{I I}$ Moreover, by expanding the observation from the criminal justice system to include administrative and military deportations, they point to the persistent relevance of punitive relocations not only for colonial, but also for metropolitan punitive regimes. The contributions also highlight the ongoing significance of penal mobility as a mode of punishment, in lieu of exclusively conflating penalty with incarceration and immobilization. From this perspective, there is more fluidity between penal transportation and incarceration than has been hitherto appreciated.

Third, this special issue points to the significant shifts that existed between early modern and modern punitive relocations, coinciding with the Age of Revolution (c.1774-I86os) and its aftermath, the rise of modern European empires, the increasingly global ambitions of the US, Russia, and Japan, and the rise of liberalism. ${ }^{\mathrm{I}}$ For instance, we highlight the connections between imperial governmentality and the late nineteenth-century

I I. See especially Florence Bernault (ed.), Enfermement, prison et châtiments en Afrique. Du Ige siècle à nos jours (Paris, 1999); Frank Dikötter and Ian Brown (eds), Cultures of Confinement: A History of the Prison in Africa, Asia, and Latin America (London, 2007).

I 2. Clare Anderson, Niklas Frykman, Lex Heerma van Voss, and Marcus Rediker (eds), "Mutiny and Maritime Radicalism in the Age of Revolution: A Global Survey", International Review of Social History, 58: Special Issue 2 I (2013); David Armitage and Sanjay Subrahmanyam, The Age of Revolutions in Global Context, C.I760-I 840 (London, 2010). On the rise of liberalism and the relationship between nation- and empire-building: Josep M. Fradera, La nación imperial (I75019I8), 2 vols (Barcelona, 20I5), I; Stefan Berger and Alexei Miller (eds), Nationalizing Empires (Budapest and New York, 2015). 
Scramble for Africa and competition in the Pacific, and the renewed importance of penal colonization. This includes Britain's use of transportation to suppress rebellion among its enslaved and colonized peoples, Russo-Japanese arguments over Sakhalin and Hokkaido, and the shift from mixed settlements of punishment and unfree labour to convict-only penal colonies. Finally, several contributions highlight the increasing impact during the period under consideration of administrative and military relocations connected to states of exception, and the "politicization" of punishment and imperial governance it implied. ${ }^{13}$

\section{IN THE COLONIES}

A distinctive feature of this special issue is its focus on an exceptionally wide range of national and imperial contexts, including not just the European empires but also European "internal" colonization and non-European colonies in East Asia. Ranging across locales as diverse as Indochina, Trinidad, Japan, the Philippines, Libya, Australia, Cuba, Russia, Siberia, India, Aceh, and Angola, the authors use penal transportation, deportation, and exile as lenses through which to view various modes of imperial governmentality, which in our collective understanding renders colonial and metropolitan contexts distinct from each other in important ways. These modes included the management of populations through geographically and economically extractive kinds of punishment, and the use of punishment to expropriate labour. Nations and empires used regional systems to inflict punitive relocations, and made racial and gender instrumental in the management and supervision of transportation, deportation, and exile. The relationship between convicts and other kinds of unfree labour is also important here. The centring of the colonies in our analysis enables us to glimpse snapshots of convict agency and creativity too, through effecting escapes and rebellions as well as expressing choice and identity in the most unpromising of penal circumstances.

Viewed from the colonies, empires look simultaneously more fragile and more violent than in their metropolitan blueprints. Colonial domination reveals itself as a complex exercise in governance, based on both repression and negotiation. The homogeneous colours of sovereignty on metropolitan maps turn into a rugged cartography of "corridors" and enclaves, including commercial and military outposts, urban centres, and religious missions. Clear-cut imperial "frontiers" appear as contested and porous borderlands, zones of contact and conflict with both indigenous peoples and competing imperial powers. The centre-periphery divide becomes populated, and contested, by a plethora of actors across multiple sites. ${ }^{14}$ The view from the

I3. Cf. Giorgio Agamben, State of Exception (Chicago, IL, 2005).

I4. Michiel Baud and Willem van Schendel, "Toward a Comparative History of Borderlands", Journal of World History, 8:2 (1997), pp. 2 I I-242; Christine Daniels and Michael V. Kennedy 
penal colonies that we propose here makes this reconceptualization of empires even more compelling. Indeed, sites of convict transportation, deportation, and exile were often keys to the further expansion of colonization, the setting of new frontiers, and the governance of peoples: this makes them ideal vantage points to observe both the precariousness and the complexity of the fabric empires were made of. From this perspective, the repeated "failure" of penal colonization to conform to the plans of imperial centres, particularly where sites were costly or rates of morbidity and mortality were high, should not be seen as a sign of their lack of success, as it is sometimes suggested. Rather, the idea of "failed" penal sites provides an entry point into the ideal of the making of empires as an ongoing process. ${ }^{15}$

As the contributions to this volume show, when the destinations of punitive relocations did emerge and persist, they were frequently as vulnerable as the imperial sovereignty that they represented and constructed. For example, Coates indicates that the tight-knit image of a model prison constructed by the authorities and colonial lobbies in Lisbon around the depósito of convicts in Luanda had little correspondence with the reality on the ground, especially in the face of convicts' frequent escapes and high mortality. Similarly, Zhanna Popova highlights the fact that even the infamous punitive regime of imperial Siberia was the product of multiple negotiations and the sum of highly uneven local circumstances, rather than a mirror for the blueprints of the imperial centre. And although such contradictions and uncertainties often accounted for the appalling conditions in which convicts lived, they also created spaces that could be used by some

(eds), Negotiated Empires: Centers and Peripheries in the Americas, I 500-I 820 (New York, 2002); Serge Gruzinski, Les Quatre Parties du monde. Histoire d'une mondialisation (Paris, 2004); Sanjay Subrahmanyam, Explorations in Connected History: From the Tagus to the Ganges (Oxford, 2005); C.W.J. Withers, "Place and the 'Spatial Turn' in Geography and in History", Journal of the History of Ideas, 70:4 (2009), pp. 637-658; Lauren Benton, A Search for Sovereignty: Law and Geography in European Empires, I400-1900 (Cambridge, 2010); Wayne E. Lee (ed.), Empires and Indigenes: Intercultural Alliance, Imperial Expansion, and Warfare in the Early Modern World (New York, 20II); Alan Lester, "Spatial Concepts and the Historical Geographies of British Colonialism”, in Andrew Thompson (ed.), Writing Imperial Histories (Manchester, 2013), pp. I I 8-I 42; Paul Readman, Cynthia Radding, and Chad Bryant (eds), Borderlands in World History, I700-I9I4 (Houndmills, 20I4); Tamar Herzog, Frontiers of Possession: Spain and Portugal in Europe and the Americas (Cambridge, MA, 201 5); Ernesto Bassi, An Aqueous Territory: Sailor Geographies and New Granada's Transimperial Greater Caribbean World (Durham, NC, 20I6); Valentina Favarò, Manfredi Merluzzi, and Gaetano Sabatini (eds), Fronteras. Procesos y practicas de integración y conflictos entre Europa y América (siglos XVI-XX) (Madrid, 2017).

I s. Discussion on the "success" or "failure" of penal colonization, considered exclusively from the perspective of the imperial authorities, is a feature of much of the historiography. See, for example, Coates, Convict Labor in the Portuguese Empire, pp. I 25-I 29; Eva Maria Mehl, Forced Migration in the Spanish Pacific World: From Mexico to the Philippines, I765-I8I I (Cambridge, 2016), pp. $258-266$. 
prisoners to their advantage. This was the case for the Indochinese exiles in French Guiana, as noted by Lorraine Paterson, and for revolts and escapes in the Philippines under US administration, as narrated by Benjamin Weber.

Empire-building and related punitive relocations were not just about controlling territories, but also, and primarily, about governing people. And, of course, one of the distinctive features of empires was the often multi-ethnic character of their populations, constituted of indigenous, enslaved, and migrant peoples and communities. The destinations of convict transportation, deportation, and exile, then, were contact zones among, and places of governmentality of, individuals subjected to multiple punitive regimes and with distinct ethnic, linguistic, and political backgrounds. Analysing them creates a unique opportunity to study the manifestations of individual and collective solidarity and conflict among prisoners, as well as the authorities' strategies of control and repression. As numerous historians have noted, the organization of race was fundamental to imperial governance. ${ }^{16}$ The question here is: did penal colonies reflect or innovate with respect to the management of empires? The answer perhaps lies in an appreciation of their role in both ways. As Anderson shows, the use of Anglo-Indian intermediaries in the Andaman Islands drew on experiences in mainland India, albeit more intensively with respect to the demography of the penal colony. The intersections with class are also important here, as highlighted by Clare Anderson, Francesca Di Pasquale, and Christian G. De Vito in relation to the differentiated destinations and treatment of elite and subaltern subjects. On the other hand, Coates' analysis shows that the penal colony in Portuguese Angola produced degrees of un-separation between Europeans, Africans, and Asians that are surprising to readers used to thinking of empires as carefully organized, racially stratified spaces.

Though empires might have used race and gender in the organization of punitive regimes, convict subjects could use them for their own purposes. Paterson, for example, analyses the remarkable journeys of political exiles from Indochina around and beyond colonial Asia, during the French imperial era. Though the French racialized transportation practices, deciding upon the suitability of French Guiana for colonially convicted transportees only during particular periods of time, it is evident from Paterson's narrative that colonized subjects created their own means of "passing", taking on Chinese identities and thus creating routes to escape repressive regimes and forge new lives. As for gender, the large majority of the penal colonies under consideration here were either largely or completely male in character. One of the gaps in our collection is a

16. David Arnold, Colonizing the Body: State Medicine and Epidemic Disease in NineteenthCentury India (Berkeley, CA, I993); Frederick Cooper and Ann Laura Stoler (eds), Tensions of Empire: Colonial Cultures in a Bourgeois World (Berkeley, CA, 1997). 
discussion of sex and sexuality, which has left few traces in the archives. Glimpses can be gained from the contributions by Paterson, Di Pasquale, and Anderson. However, it is clear that for most contexts we still lack sophisticated analyses of sexuality and gender relations like those produced by Joy Damousi and Kirsty Reid for the Australian colonies, Anderson for the Indian Ocean world, and Dan Healey for the USSR. ${ }^{17}$

To write of race, gender, and identity, with an attention that lies close to the concerns of New Imperial History, and to speak of punitive sites as "contact zones" is not to downplay the brutality of convict labour regimes. Indeed, in Japan up to one third of convicts died during road construction in the penal colonies of Hokkaido. ${ }^{18}$ The repression of political prisoners could be particularly violent too, as in the case of the American Philippines (Weber). And as Matthias van Rossum shows for the Dutch East Indies, in common with many other sites of punitive relocation, penal transportation co-existed with corporal punishment and chain-gang labour, including on the roads and in the particularly harsh environment of coal mines. Moreover, the function of punishment vis-à-vis labour relations was broader than the direct production of convict labour. It played a central role in disciplining other contract and coerced workers, such as enslaved people, indentured servants (European and Asian), and corvée labourers. ${ }^{19}$

Following the traces of transported convicts implies addressing the minute geographies of colonization, and makes us aware of the importance of spatiality in managing convicts within colonies. For example, Katherine Roscoe looks closely at the islands off the coast of the Australian colonies and foregrounds their multiple functions within the imperial project. Weber provides a detailed account of how the various parts and populations of the Philippines were conceptualized during US (and Spanish) colonial rule. Popova names the specific sites of punishment within Eastern and Western Siberia - from Tobolsk to Sakhalin - instead of referring to that vast region as one uniform entity. This spatial awareness is necessary, for the unevenness of colonial geography was precisely the basis for the creation of regional systems of punishment. Indeed, translocal flows of transportation,

17. Joy Damousi, Depraved and Disorderly: Female Convicts, Sexuality and Gender in Colonial Australia (Cambridge, 1997); Kirsty Reid, Gender, Crime and Empire: Convicts, Settlers and the State in Early Colonial Australia (Manchester, 2007); Clare Anderson, Subaltern Lives: Biographies of Colonialism in the Indian Ocean World, I790-I920 (Cambridge, 20I 2); Dan Healey, Russian Homophobia from Stalin to Sochi (London, 2017), ch. I. See also Abby M. Schrader, "Unruly Felons and Civilizing Wives: Cultivating Marriage in the Siberian Exile System, I $822-$ I 860", Slavic Review, 66:2 (2007), pp. 230-256.

I8. Minako Sakata, "Japan in the i 8th and I9th Centuries", in Anderson, A Global History of Convicts and Penal Colonies, pp. 307-335.

19. See also Clare Anderson, "Transnational Histories of Penal Transportation: Punishment, Labour and Governance in the British Imperial World, 1788-1939", Australian Historical Studies, 47:3 (20I6), pp. 38 I-397. 
deportation, and exile between the colonies fed the Siberian punitive system, together with those that originated in the Western part of Russia. Intracolonial relocations were the exclusive sources of the punitive systems in the Philippines under US rule (Weber), in the Australian colonies after the discontinuation of transportation from Britain (Roscoe), in British India (Anderson), and in the Dutch East Indies (Van Rossum). Punitive systems generated in colonized localities additionally constructed connections between colonies. Examples here include Mozambique and Angola (Coates), Cuba, Fernando Poo, and the Philippines (De Vito), and Indochina and Gabon, Algeria, and Tahiti (Paterson). Many of the regional systems in evidence here entirely circumvented what are usually viewed as centres of political and other forms of imperial or territorially acquisitive power. In this regard, this issue adds weight to the historiography of interimperial transportation, taking it into new contexts and highlighting its nature, extent, and importance.

The decentring of European metropoles in the analysis proposed in this volume also pushes us to ask a key question: As a locus of imperial power, where was the metropole? Though this term is used widely in global and imperial history, its origins lie within a rather particular context: imperial France. ${ }^{20}$ Historically, contemporaries in France and the French Empire used the term to refer to European France. In a post-colonial context in which many of the former colonies remain, politically, overseas dependencies (départements d'outre-mer), and thus part of the European Union, the word "metropole" remains widely used today. As a shorthand for the organization and hierarchies of all empires, does it work? We are uncertain. Up to the independence of Latin America in the early nineteenth century, the Spanish Empire is a case in point, for the system of viceroyalties was grounded in numerous imperial centres. There are similar points to be made regarding the British Empire in the later period. As Roscoe shows, the Australian colonies themselves managed the continent's carceral islands. These islands lay at the geographical peripheries of the colonies, twice removed from the Colonial Office in London, and their utility generated out of the distinctive concerns of Australian imperial governors and officials. To take another example from the British Empire, the Andaman Islands penal colony (see Anderson) received convicts from all over the mainland Indian Empire, which at the time encompassed a vast area that stretched from what is now Pakistan and Bangladesh to the southern coast of India, and around the rim of the Bay of Bengal to Myanmar (then known as Burma). Its imperial centres were located in Delhi and the Indian presidencies of Bengal, Bombay, and Madras, far from the British Isles. 
A decade ago, John Darwin attempted to capture the diffuseness of the British Empire by defining it as an imperial project, reaching into many areas of social, cultural, and economic life all over the globe, but by no means as a unified entity. ${ }^{2 \mathrm{I}}$ This issue, centred on peoples and places marginalized by empire and by punitive relocation, seeks to push this important insight further. By focusing on convicts and penal colonies, and in particular by highlighting the significance of regional systems of transportation, deportation, and exile, we show that there is no easy answer to the question of where "the metropole" lies. Certainly, from a Eurocentric perspective, the answer might be clear: in European capitals, or their equivalents in other parts of the world. From the perspective of the colonies, the answer is rather less certain. We could propose to call them "colonial metropoles" - centres of imperial power that lay beyond nation states, sometimes amorphous, often mobile, and frequently shifting.

\section{COLONIES AND METROPOLES}

The relationship between imperial centres and their colonies constitutes another important focus throughout this special issue. Several contributions make it evident that imperial centres usually avoided colony-to-centre punitive relocations, thus constituting European cities and their hinterlands as effectively separated and "protected" legal spaces (Van Rossum, Sakata, Popova, Coates, and De Vito). On the rare occasions that empires shipped colonial convicts to Europe, they almost exclusively took the form of the repatriation of white settlers accused of crimes, or the administrative deportation or exile of elites. The Italian case is the striking exception. As Di Pasquale points out in her chapter, in the Liberal period (I 86I-I922) judicially sentenced convicts flowed from Libya towards Italy, alongside exiles and individuals deported on military orders. This was the result of the precarious hold on the newly colonized overseas territories, and of the fact that the south of Italy and the island of Sardinia were not only conceptualized as in need of internal colonization, but also as "colonial" territories themselves.

This special issue addresses the more usual pattern of centre-to-colony punitive relocations against the background of the changes in the spatiality and conceptualization of empires in the aftermath of the Age of Revolution (c.I774-I860s). The Atlantic Revolutions of the late eighteenth and early nineteenth centuries obliged the majority of the Western empires to search for new sites of banishment, deportation, and transportation. In the transition from their "first" to "second" empires, for example, the British 
largely re-routed metropolitan convicts from North America to the littorals of West Africa and then to the Australian colonies. Though before the American Revolution the French had shipped convicts to Louisiana, as they gradually occupied new overseas territories they began to send convicts to French Guiana and New Caledonia. Expelled from Brazil in the early I 820 s, the Portuguese similarly sought to enhance the exploitation of their African colonies in Angola and Mozambique, and established depósitos of convicts. Finally, Spain struggled to replace the flows of penal transportation to the lost viceroyalties of South America with punitive relocations towards its remaining three colonies (Cuba, Puerto Rico, and the Philippines), the North African presidios, or military outposts, and newly acquired possessions such as Fernando Poo and the Carolina Islands.

The effects of the Age of Revolution were even deeper than those significant geographical reconfigurations of empires and related convict flows suggest. The transition from ancient to constitutional regimes in many locations meant that the characteristic legal pluralism of the ancien régime was tendentially replaced with a unified legal space. As liberalism advanced in metropolitan Europe, all Western imperial powers had to determine whether, and how far, colonial subjects should enjoy emancipation, citizenship, and/or political representation. ${ }^{22}$ For example, with respect to the outreach of the metropolitan legal regimes: Were the overseas territories to be governed by the same constitutions and legislation as the metropole, or did their different ethnic and social composition, and their allegedly inferior level of "civilization", require exceptional laws? And should all colonies within empires be governed by the same laws? The answers to these questions differed, and a focus on nineteenth-century metropole-tocolony penal transportation offers a privileged entry point into that variation. Indeed, the transportation of judicially sentenced convicts from European nations to overseas territories was in some cases a sign of the extension of the metropolitan legal regime (including the penal code) to the whole empire. This was the choice made by French legislators, reflecting the universalistic tradition of the Revolution of 1789 and the long-standing hegemony of the principle of assimilation in French colonial policy. Therefore, once a new imperial balance was found around the mid-nineteenth century, flows of penal transportation took approximately 70,000 sentenced convicts (transportés) - including some 2,000 women from France to French Guiana and New Caledonia, the last of them not repatriated until after World War II. ${ }^{23}$ The Portuguese expressed a similar

22. See especially Fradera, La nación imperial; Berger and Miller, Nationalizing Empires.

23. Peter Redfield, Space in the Tropics: From Convicts to Rockets in French Guiana (Berkeley, CA, 2000); Louis-José Barbançon, L'archipel des forçats. Histoire du bagne de Nouvelle-Calédonie (I 863-193 I) (Pas-de-Calais, 2003); Danielle Donet-Vincent, De soleil et de silences. Histoire des bagnes de Guyane (Paris, 2003). On French colonial theory, see Raymond F. Betts, 
preference through their legal codes of the i 860 s and i 870 s, and from the I 880 S to I 932 transported I 6,000 to 20,000 sentenced convicts (degredados) to their possessions in Angola and Mozambique. ${ }^{24}$

Other imperial nations took the opposite direction. They highlighted the legal distinction of the colonies vis-à-vis the metropole, and accordingly discontinued or banned penal transportation from the metropole to the colonies. Together with the colonies' opposition to new arrivals of convicts, this was the underlying reason for the end of penal transportation from Britain and Ireland to the Australian colonies. However, in British Asia laws of penal transportation, largely imported from those of the British Isles, led to the creation of the single largest penal colony in the whole British Empire - the Andaman Islands (1793-1796, I $858-1945) .{ }^{25}$ In the same way, the regional character of the circuits of penal transportation in the Dutch East Indies, addressed by Van Rossum, stemmed from the discontinuation of metropolitan convict transportation after the shift from the sprawling Dutch East India Company's settlements to that of the geographically contracted Dutch East Indies. Spain, in turn, is a telling example of the shift that occurred in the first few decades of the nineteenth century: from universalist-inspired "imperial" constitutions to "colonial" constitutions based on the distinct legal status of the colonies. While Cuba, Puerto Rico, and the Philippines continued to be conceptualized as "provinces" throughout the century, hinting at a model of full assimilation in the metropolitan legal space, from the I 830 on onwards they were subjected to a special legal status. ${ }^{26}$ As De Vito explains in his chapter, this led to the discontinuation of the centuries-long practice of sending judicially sentenced individuals from Spain to the colonies. At the turn of the nineteenth century, during intense debates in the Reichstag, the new nation state and imperial power of Germany chose to avoid convict transportation to its colonies. ${ }^{27}$ Finally, the US never considered sending American citizens to its colonies in the Philippines or Puerto Rico, and only briefly discussed the possibility of sending US convicts to work on the Panama Canal. When a project for the establishment of a penal colony materialized in the I870s and I 880 s, the envisaged location was Alaska, which was at once distant from and part of metropolitan legal space. That plan was never implemented, but

Assimilation and Association in French Colonial Theory, I890-19I4 (Lincoln, NE, I960); Alice L. Conklin, A Mission to Civilize: The Republican Idea of Empire in France and West Africa, I8951930 (Stanford, CA, 1997). While arguing that a shift from assimilation to association took place in French colonial theory in the two decades before World War I, Betts acknowledges that the practical impact of such transformation was limited (particularly outside Indochina and North Africa). There is no sign of a move away from assimilation in the legal field.

24. See also Coates, Convict Labor in the Portuguese Empire.

25. Anderson, "Transnational Histories of Penal Transportation".

26. Josep M. Fradera, Colonias para después de un imperio (Barcelona, 2005).

27. Fitzpatrick, Purging the Empire, especially ch. I (pp. 19-38). 
it resonates with the insistent arguments of contemporary criminologists, penal reformers, and policymakers in various empires that the global powers could best use convict labour to expand internal frontiers, rather than getting involved in penal colonization overseas. ${ }^{28}$

Renouncing the use of the criminal justice system to remove individuals from Europe to overseas possessions did not amount to the suspension of metropole-to-colony punitive relocations. Indeed, even when penal transportation was discontinued or fell out of use, administrative and military relocations continued. For example, though Germany avoided penal transportation, it did not exclude what Matthew Fitzpatrick has described as "more inventive legal means" of forced removal. Special laws legitimated the administrative expulsion of groups of Jesuits in I872, socialists and Poles in the I880s and I890s, and Roma in the early I900s. ${ }^{29}$ In this regard, De Vito shows how administrative and military deportations in the Spanish Empire became tools for the creation of connections between the metropole and the overseas provinces. Such punitive practices, based on the declaration of states of exception, were grounded in constitutional and legislative codes. As such, as De Vito shows, they were neither arbitrary nor contrary to the legal regime, but stemmed from, and were entirely legitimated by, constitutional legality. ${ }^{3 \circ}$

Meanwhile, those imperial states that practised penal transportation extensively used both administrative and military deportation too. France is a case in point. In addition to overseeing the shipment of transportés, sentenced under ordinary criminal law, between I 887 and I 949 the French authorities deported over 22,000 repeat offenders (including approximately I,000 women) to French Guiana and New Caledonia under the administrative regime of relégation. At the same time, an even larger number of "unruly" soldiers were relocated to the North African military institutions informally known as "Biribi". These included disciplinary battalions, military prisons, the African Corps (Bat' d'Af'), and the sections for men who were otherwise excluded from joining the army due to previous criminal convictions. Parts of

28. Benjamin Weber, “America's Carceral Empire: Confinement, Punishment, and Work at Home and Abroad, I865-1946” (Ph.D., Harvard University, 2017). On internal penal colonization, see, for example, Mario Da Passano (ed.), Le colonie penali nell'Europa dell'Ottocento (Rome, 2004); Fernando José Burillo Albacete, La cuestión penitenciaria. Del Sexenio a la Restauración (I868-1913) (Zaragoza, 20II), pp. I9I-208; Mary Gibson and Ilaria Poerio, "Modern Europe, 1750-1950", in Anderson, A Global History of Convicts and Penal Colonies, pp. $337-370$.

29. Fitzpatrick, Purging the Empire, p. 38 .

30. For a similar argument, see Nasser Hussain, The Jurisprudence of Emergency: Colonialism and the Rule of Law (Ann Arbor, MI, 2003); Francesco Benigno and Luca Scuccimarra (eds), Il governo dell'emergenza. Poteri straordinari e di guerra in Europa tra XVI e XX secolo (Rome, 2007); Julie Evans, "Colonialism and the Rule of Law: The Case of South Australia", in Barry Godfrey and Graeme Dunstall (eds), Crime and Empire 1840-1940: Criminal Justice in Local and Global Context (Routledge, 2012), pp. 57-75; Fitzpatrick, Purging the Empire. 
that complex punitive system remained operational until decolonization in the I970s. ${ }^{3 \mathrm{I}}$

So far in this section we have discussed the experience of punitive relocations to and among overseas colonial possessions. Russia and Japan are slightly different cases as their expansion was contiguous from the centre. This configuration implied a tendency to legal assimilation, as new territories were progressively annexed to the core regions. In these cases, the distinction between "metropoles" and "colonies" was blurred, and often absent altogether. Indeed, Minako Sakata notes that, in Japan in the late nineteenth and early twentieth centuries, elites altogether rejected the concept of "empire", possibly due to its association with Western colonization. Both Sakata and Popova, however, caution us against stretching this linear interpretation of legal assimilation too far, not least because simultaneous with Japan's legal incorporation of Hokkaido was its i 895 occupation of Taiwan and I9I0 annexation of Korea. In the former case, Japan refused to receive Taiwanese inmates. ${ }^{32}$ Indeed, constructed and real distinctions between core regions and borderlands mattered where penal transportation was concerned. As Popova shows, penal reforms designed at the centre of Russia's empire did not correspond to the situation at its peripheries, especially in newly colonized territories such as late nineteenth-century Western Siberia. Local officials there heavily influenced the implementation of punitive policies.

The relationship between core regions and borderlands was even more complex in the islands of Japan, because territorial contiguity was mediated by the sea. The policy of "extending homeland ideology", as Sakata tells us, de facto acknowledged the need for a transitional period before the new territories could be fully assimilated. This produced a fascinating situation in the island of Hokkaido. The relocation of sentenced convicts from "mainland" to "island" was labelled "penal transportation" during the transitional period, and was called "incarceration" after Hokkaido became part of Japan. That shift was prompted also by a switch in the Western model of penal reform initially followed by the Japanese authorities. Indeed, the French influence that had originally supported the introduction of penal transportation was replaced by the German model, which rejected the practice of convict transportation. This reminds us that nineteenthcentury non-Western empires cannot be studied in isolation from their Western counterparts, given the intense global circulation of legal ideas and practices that existed during this period. In fact, while the Japanese case is not an example of mutual influence, ideological reciprocity certainly existed in the case of Russia. Western ideas of penal reform impacted on the ideas of

31. Dominique Kalifa, Biribi. Les bagnes coloniaux de l'armée française (Paris, 2009).

32. Daniel V. Botsman, Punishment and Power in the Making of Modern Japan (Princeton, NJ, $2005)$, p. 207. 
Tsarist officials, while penal transportation in the Russian Empire was also constantly mentioned by criminologists and policymakers in other nations, in the context of their desire to introduce or reintroduce that punitive practice into Western penal codes.

\section{PUNITIVE RELOCATIONS AND INCARCERATION}

Between I 872 and I910, the meetings of the International Prison Congress provided a key forum for the exchange of information about penal reform. Their published reports represent important sources in order to understand the level of global circulation of ideas around crime and punishment. Especially relevant are the proceedings of the congresses held in Stockholm in 1878 and in Paris in I 895, where the question of transportation was addressed extensively. ${ }^{33}$ However, the parallel analysis of those documents with the scholarship on penal transportation reveals several ways in which the International Prison Congress provided a myopic view on the historical reality of penal transportation and incarceration. Highlighting those shortcomings gives us the scope to expose some of the analytical flaws of contemporary representations of the history of the prison, which closely resemble those of the Congresses' participants. On this basis, we can also point to some of the contributions of this special issue to a new understanding of the character of nineteenth- and twentieth-century punishment.

The impact of the International Prison Congress on penal policy and practice is hard to measure. Indeed, many of the participants' perspectives reflected their interest in penal systems and institutions rather than the daily life of punitive sites. These experts occupied themselves with theoretical blueprints rather than with the organization of punishment on the spot. And they interpreted the contradictory information and statistics gathered on specific experiences of imprisonment and transportation for the sake of strengthening their own theoretical positions. The endless debates on the success or failure of British transportation to Australia, which reproduced similar discussions at national level, are a case in point, as those experiences provided arguments for both supporters and critics of penal transportation. ${ }^{34}$

Moreover, the allegedly "international" nature of the Congress contrasts with its largely Western focus and deeply Eurocentric approach. Nir Shafir has shown that the Western organizers' perception of the countries' drive towards (Western-like) "civilization" played a primary role in the composition of the guest lists. Furthermore, the danger that a colony or

33. Briony Neilson, "The Paradox of Penal Colonization: Debates on Convict Transportation at the International Prison Congresses I872-1895", French History and Civilization, 6 (2015), pp. I98-2II.

34. See, for example, Burillo Albacete, La cuestión penitenciaria, pp. 62-67; Neilson, "The Paradox of Penal Colonization". 
non-Western country might take part in the Congress on the same footing as a Western colonial power led to their gradual exclusion after the I870s, including in the case of British India, then the site of some of the world's biggest prisons and a key laboratory of penal theories and practices. The remaining non-Western actors were expected to act as "silent spectators", the passive recipients of Western ideas. ${ }^{35}$

Unsurprisingly, this Eurocentric perspective resulted in a focus on penal transportation outwards to colonies, to the exclusion of intra- and intercolonial punitive relocations. The practices of colonial incarceration were silenced too. However, as a relatively broad scholarship has foregrounded in the last two decades, the history of the colonial prison is key to a critical reconsideration of the nature of incarceration during the nineteenth and early twentieth centuries, and especially its coexistence with punitive violence and forced labour. ${ }^{36}$ This special issue takes this argument further, by revealing genealogies of the prison - both in the colonies and in imperial centres - that go back to military practices, rather than to, as is often claimed, enlightened penal theories and what Norbert Elias famously called "the civilizing process". ${ }^{37}$ Moreover, it shows the persistent connection between imprisonment and forced labour in the colonies, in the form of both direct exploitation of convict labour outside the walls of the prison and the use of incarceration to manage the coerced workforce of enslaved people, corvée labourers, and indentured servants. Further, it reveals the nature and scale of punitive relocations between and across colonies, which in some cases was unrelated to the institution of the prison.

The dominant discourse emerging from the International Prison Congresses was one that contrasted penal transportation and imprisonment with the aim of establishing the most appropriate and "modern" form of punishment. Indeed, as Briony Neilson has observed and the name of the Congress betrayed, even the organizers of the gatherings were partisans in that confrontation, showing a tendency to "implicit resistance" or "suspicion" towards penal transportation. ${ }^{38}$ More detached readers of the

35. Nir Shafir, "The International Congress as Scientific and Diplomatic Technology: Global Intellectual Exchange in the International Prison Congress, i 860-90", Journal of Global History, 9: I (2014), pp. 72-93. On the prison system in British India, see, especially, David Arnold, "India: The Contested Prison", in Dikötter and Brown, Cultures of Confinement, pp. 147-184; Clare Anderson, The Indian Uprising of 1857-8. Prisons, Prisoners and Rebellion (London, 2007), especially pp. $26-54$.

36. See especially Ricardo D. Salvatore and Carlos Aguirre (eds), The Birth of the Penitentiary in Latin America: Essays on Criminology, Prison Reform, and Social Control, 1830-1940 (Austin, TX, 1996); Bernault, Enfermement, prison et châtiments en Afrique; Dikötter and Brown, Cultures of Confinement; Gibson, "Global Perspectives on the Birth of the Prison".

37. Norbert Elias, The Civilizing Process (London, 1939); Garland, Punishment and Modern Society, ch. Iо.

38. Neilson, "The Paradox of Penal Colonization", p. I I. 
proceedings might note that the symmetrical nature of the arguments used by the supporters of the two systems implied that they shared at least two characteristics: they were both designed to have deterrent as well as rehabilitative functions, yet they systematically failed to meet their own goals, and therefore attracted constant and often sound critiques. Neither of the two, therefore, appeared an ideal solution to contemporaries, which possibly explains why the debate among experts continued for several decades.

By looking at the situation from the vantage point of punitive sites in the colonies, collectively the chapters add an extra dimension to this discussion. Namely, they foreground the fluidity that existed between penal transportation and incarceration, which were overlapping and co-existent at various levels. Indeed, it was not only in Hokkaido that the practices of transportation and imprisonment were overlaid. Weber shows here that this was the case in the Philippines under US rule, due to the simultaneous need to prevent prison revolts and split up and secure the insurgents. The outcome of that double process was a complex network of punitive sites called prisons and penal colonies, which presented striking similarities with the map of penal transportation under nineteenth-century Spanish rule. Moreover, De Vito describes how, within the Spanish metropolitan legal space, the incarceration of hardened criminals in Ceuta and the other North African presidios amounted to their transportation from peninsular Spain to the other side of the Mediterranean. More broadly, these examples are reminders of the importance that spatial mobility played (and arguably still plays) within prison systems, and of the role of immobilization within regimes of penal transportation.

More specific practices implied significant levels of connection between incarceration and penal transportation. Discussing punitive relocations from mainland British India to the Andaman Islands, for example, Anderson mentions the transfer of European and Eurasian prisoners on licence and, later, of "volunteer" Indian prisoners, and supposedly hereditary criminals belonging to groups labelled by the British as "criminal tribes". Similarly, according to De Vito, convicts held in the Spanish prisons and the North African presidios "volunteered" to join the imperial army at the time of the colonial wars in Santo Domingo, Puerto Rico, and Cuba. With respect to the latter, the authorities de facto extended penal transportation to the overseas provinces without creating a unified legal space including both the metropole and the colonies. Penal transportation could also complement imprisonment as a phase of the enforcement of sentences, with transportation to internal and overseas penal colonies standing between a period of imprisonment and release. In other cases, relocation to penal colonies was introduced as an "eliminative" punishment for recidivists and "professional delinquents" who had allegedly proven incompatible with the prison regime or who were seen as "incorrigibles". 
The practice of relégation across the French Empire and the newly established penal colonies in Latin America were connected to this trend, as were the deportations of Cuban incorregibles to the Isle of Pines, Fernando Poo, and the Philippines.

Finally, this special issue shows that the connectivity of punitive regimes was not limited to the linkage of different kinds of convicts and prisoners, or to the relationships between prisons and penal transportation. Rather, punitive regimes incorporated a whole range of practices that stemmed from military and administrative relocations from, among, and to the colonies. It is perhaps unsurprising that these were not addressed in the International Prison Congresses, which by definition restricted their focus to the issue of penal reform. However, the marginalization or outright removal of those practices from the scholarship on punishment is problematic. By widening the lens beyond the criminal justice system, the contributions presented here show that only by taking those punitive relocations into account can we reach a balanced assessment of punishment from the nineteenth to the mid-twentieth centuries. This moves us away from the untenable but still strong narrative of the irresistible rise of the penitentiary, and towards a recognition of the ongoing significance of punitive relocation, or punitive mobility, within the more expansive and transnational history of punishment that we propose here. Indeed, when administrative and military deportation are considered alongside punishments that stemmed from the criminal justice system, the role of incarceration appears less prominent, and certainly not exclusive, not only in the colonies but also in Europe.

Our acknowledgement of the importance of administrative and military deportations in a number of contexts requires further exploration, because it has the potential to integrate the history of nineteenth- and early twentieth-century punitive relocations with studies of mass deportation under Fascist and Soviet regimes later on. The timing seems appropriate for such an endeavour. Until recently, the separation of the scholarship on imprisonment from that on penal transportation and twentieth-century concentration and labour camps had produced a paradoxical vision of the twentieth century in which the age of the penitentiary and the century of the camps are presented as mutually exclusive. ${ }^{39}$ A key exception is the work of Lynne Viola, who has unveiled the "unknown Gulag" of the special settlements, integrating the study of penal transportation with an analysis of administrative relocation. In so doing, she has additionally stressed the continuity between Tsarist and Stalinist practices of punitive relocation, 
both of which had the goal of "internal" colonization. ${ }^{40}$ At the same time, Nikolaus Wachsmann's Hitler's Prisons has foregrounded the role of the criminal justice system and state prisons in the broader punitive practices of the Third Reich. A more recent edited volume has expanded this approach to a broader set of Western European countries and to a larger range of punitive regimes. ${ }^{4 \mathrm{I}}$ Finally, several scholars have searched for colonial antecedents for twentieth-century mass deportation and concentration camps, pointing to global circulations of ideas, practices, and officers. ${ }^{42} \mathrm{By}$ proposing a view that integrates punitive relocations with incarceration, across numerous global contexts, this special issue contributes to this conversation.

In the chapters that follow, the authors centre on a diversity of global contexts, distinguished by various configurations and reconfigurations of spatial hierarchies, different ideas about the geopolitical borders of colonies, and diverse and distinctive relationships between centres and peripheries. They take different approaches to the perspective from the colonies, but each is committed to the elaboration of a history of convicts and penal colonies that begins in what are often considered the peripheries of empires. This enables the collection to forge new connections between histories of governmentality, punishment, and labour, and the new imperial histories of race, class, and gender. This included, as Clare Anderson shows, the employment of Anglo-Indian intermediaries in the Indian penal colony of the Andaman Islands, where crime was forgotten in lieu of the privilege of class. When the number of Anglo-Indians proved inadequate, and the drive to encourage free settlement in the Islands failed, the government of India

40. Lynne Viola, The Unknown Gulag: The Lost World of Stalin's Special Settlements (Oxford, 2007).

4I. Nikolaus Wachsmann, Hitler's Prisons: Legal Terror in Nazi Germany (New Haven, CT, 2004); Christian G. De Vito, Ralf Futselaar, and Helen Grevers (eds), Incarceration and Regime Change: European Prisons During and After the Second World War (New York, 2016). See also Aidan Forth, Barbed-Wire Imperialism: Britain's Empire of Camps, I876-I903 (Berkeley, CA, 2017).

42. Benjamin Madley, "From Africa to Auschwitz: How German South West Africa Incubated Ideas and Methods Adopted and Developed by the Nazis in Eastern Europe", European History Quarterly, 35:3 (2005), pp. 429-464; Klaus Mühlhahn, "The Concentration Camp in Global Historical Perspective", History Compass, 8:6 (2010), pp. 543-56r; Jonathan Hyslop, "The Invention of the Concentration Camp: Cuba, Southern Africa and the Philippines, I 896-1907", South African Historical Journal, 63:2 (2002), pp. 25 I-276; Jonas Kreienbaum, "Deadly Learning? Concentration Camps in Colonial Wars Around 1900", in Volker Barth and Roland Cvetkovski (eds), Imperial Co-Operation and Transfer, I870-1930: Empires and Encounters (London, 2015), pp. 219-235. For different perspectives, see also Karsten Linne, “The 'New Labour Policy' in Nazi Colonial Planning for Africa”, International Review of Social History, 49:2 (2004), pp. 197224; Patrick Bernhard, "Hitler's Africa in the East: Italian Colonialism as a Model for German Planning in Eastern Europe”, Journal of Contemporary History, 5 I:I (2016), pp. 6I-90. 
targeted other marginalized populations in programmes of carceral mobility, including volunteer prisoners, anti-imperial rebels, and so-called criminal tribe families. This imperial space was managed by an Indian metropole, and its social formations resembled more those of another such periphery, Burma, than those of mainland India itself.

Islands and island archipelagos like the Andamans were attractive as sites of penal transportation for two reasons: they had natural features that enhanced convict containment, and they were often situated along trade routes or near mainland nodes of colonization and trade, making occupation desirable. The relationship between continents and islands is the focus of Katherine Roscoe's analysis of the carceral islands of Britain's Australian penal colonies. She illuminates their multi-faceted character and connections: as harsh locales for the additional punishment of transportation convicts already transported to the Australian colonies, as culturally feared places for the punishment of indigenous people, and as centres of production and in which convicts and prisoners built the maritime infrastructure necessary to encourage and enhance networks of imperial trade. Understanding the racial stratifications within and between islands as carceral spaces enables a deconstruction of imperial ideologies of labour capacity, as well as an appreciation of the deep paradox of carcerality-producing connectivity.

Labour coercion and worker management is also central to Matthias van Rossum's analysis of punitive relocations across the Dutch East Indies. Not only do these reveal the relationship between one European metropole and its Asian colonies in the accumulation and globalization of capital, they also show the connected character of punishment and labour exploitation. As in the nineteenth-century Australian colonies, convicts were the consequence of particular kinds of imperial governmentality; they were not entirely separated from other forms of coerced labour, but worked alongside them in a networked system. This was also the case in Indochina, which as Lorraine M. Paterson reveals produced staggering numbers of convicts during the period of French occupation. However, the inability of the colonial authorities to prevent convict flight, coupled with the extent of Chinese labour mobility during this vital period of global migration, opened up racialized spaces in which Indochinese convicts could "pass" as free. This enabled remarkable forms of self-reinvention, including through family formation in new locations. Not only does this analysis of intercolonial constraint and mobility radically alter perspectives on the character of the penal colony of French Guiana, we see something of the extent of connections between empires, as convict agency and mobility straddled French and British possessions in the littorals and islands where the Atlantic Ocean meets the Caribbean Sea.

Minako Sakata shifts the focus to the Pacific, writing of the penal colonies of the Japanese possession of Ezochi (Hokkaido) at the turn of the 
twentieth century, and arguing that the island's eventual incorporation into Japan's empire created legal tangles around what constituted a colony and thus the possibility of penal transportation. In this way, the article traces a key point in the emergence of a terminology of Japanese imperialism, later used with respect to Taiwan and Korea: "extending homeland ideology". It shows how penal colonization had the dual function of displacing the island's indigenous peoples, and supplying a vital labour force for the building of roads into the interior. Like Japan, Russia is often absent from comparative histories of empire. Zhanna Popova's article focuses on the Siberian peripheries to appreciate the centripetal and spatially complex character of exile, its entanglements with other imperial practices, and debates about transformations in the geopolitics of "the colony". It hazards against generalizations about punitive relocation, for it presents an image of exiles abandoned rather than controlled by the state. Moreover, depending on the specific context, exile was sometimes connected or separated from the punishment of penal labour.

In Timothy J. Coates' investigation, the Depot for Transported Convicts in Angola is a lens through which we can see the changing configurations of punishment, development, urbanization, emigration, and settlement played out in imperial Portugal. Drawing on a rare glimpse of convict experience, Coates employs two published accounts of the pro-republican journalist João Pinheiro Chagas to connect together international circulations of penal knowledge, European rivalry in the continent of Africa, and the economic consequences of the abolition of slavery. Again, punitive relocation opens out for interrogation some of the key questions of imperial and global history, as well as their relationship to the distinction and management of crime, race, and gender on the ground. As in the British, French, Russian, and Portuguese empires, Spanish punitive locations received convicts from imperial centres and peripheries. Christian G. De Vito gives a rich account of the directionality of these flows, and the connections between judicial, administrative, and military transportation, and between transportation and incarceration. He foregrounds the impact of the militarist tradition in the Spanish Empire and the related extensive use of the state of exception, both in the overseas provinces and in the Spanish Peninsula. Furthermore, he notes that punitive relocations were a means of managing workers, slaves, and rebels.

The confinement of anti-imperial rebels in carceral institutions and the relationship between penal transportation and incarceration are also central themes in Benjamin Weber's contribution, on the American-occupied Philippines. The multi-directional circulation and mobility that characterized American practices were, in his analysis, legacies of the Spanish Empire. It was premised on the production of spaces organized along particular combinations of criminality, race, ethnicity, and gender. Moreover, the history of punishment in the archipelago was connected to 
the history of revolt, not solely because it was deployed to counter insurgents, but because it provided a space for the emergence of new kinds of political consciousness. Finally, Francesca Di Pasquale's examination of deportation from the African colonies to Italy returns to the theme of extrajudicial forms of punishment and their relationship to imperial governmentality. Convicts tended to flow outwards to borderlands, frontiers, or colonies, or between imperial possessions, and the directionality of the Italian flows generated out of imperial repression is remarkable. They can be explained through an appreciation of the relatively short distance between Italy and its North African possessions, the comparatively limited extent of the Italian Empire, and racialized representations of Italy's south, in which the empire's carceral institutions were located.

The articles in this special issue bring together expertise from different contexts, united by the common purpose of beginning their respective analysis outside of Europe, and in the colonies. They address a set of common problems. These include the way in which penal transportation, deportation, and exile created and recreated spatial hierarchies, according to particular intersections with race, class, labour, and punitive regimes. The breadth and variability of the spaces that concern us, from huge labour camps to tiny convict outposts, situated in every populated continent of the world, enable us to view the multiple functions served by punitive mobility, and in particular the way in which it lubricated the expansion, reshaping, and management of empires. Our focus on a specific moment in time, the nineteenth and twentieth centuries, reveals the importance of punitive relocation during a period most usually associated with the rise of the prison. We contend that the history of punishment cannot be separated from changes in the structure and conceptualization of empires during this period. When punishment and the geopolitics of empires are viewed in the same global frame of analysis, transportation, exile, and deportation are revealed as pervasive, enduring, and highly significant in terms of governmentality, punishment, and labour extraction. Moreover, the idea of the penal colony explodes the distinction between the accepted concepts of "cores" and of "colonies". Not only did the routes, circuits, and networks of convict mobility create new spatial hierarchies among the global powers, they enabled agency and resistance by transported, exiled, and deported people. In this respect, the perspective from the colonies reveals a new picture of empire- and nation-building in the nineteenth and twentieth centuries, and of the ambivalence of subaltern engagement with and resistance to them. 